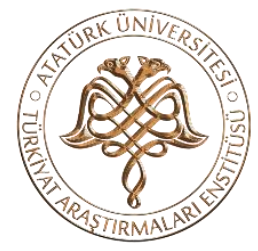

\title{
SOLAK-ZÂDE TARIHII
}

\section{THE HISTORY OF SOLAK-ZÂDE}

\section{SÜLEYMAN LOKMACI}

Dr. Öğr. Üyesi Erzincan Binali Yıldırrm Üniversitesi Assist. Prof. Dr. Erzincan Binali Yıldırm University slokmaci@erzincan.edu.tr

iD https://orcid.org/0000-0001-8526-1725

Türkiyat Araştırmaları Enstitüsü Dergisi-Journal of Turkish Researches Institute

TAED-63, Eylül-September 2018 Erzurum

ISSN-1300-9052

Makale Türü-Article Types : Araştırma Makalesi-Research Article

Geliş Tarihi-Received Date : $\quad 05.02 .2018$

Kabul Tarihi-Accepted Date : 11.05 .2018

Sayfa-Pages : $515-531$

doi : http://dx.doi.org/10.14222/Turkiyat3885

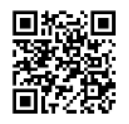

www.turkiyatjournal.com

http://dergipark.gov.tr/ataunitaed

This article was checked by

iThenticate 



\title{
ATATÜRK ÏIIVERSIIIISSI \\ TÜRKIYAT ARAŞTIRMALARI ENSTITÜSÜ DERGISI \\ JOURNAL OF TURKISH RESEARCHES INSTITUTE \\ TAED-63, 2018. 515-531
}

\author{
SOLAK-ZÂDE TARİHİ \\ THE HISTORY OF SOLAK-ZÂDE
}

SÜLEYMAN LOKMACI

Öz

Solak-zâde Mehmed Hemdemî Çelebi 17. yüzyllda İstanbul'da yaşamış tarihçi, şair ve bestekârdır. Hakkında çok az bilgi sahibi olduğumuz Solak-zâde şiirlerinde "Hemdemî" musikîde ise "Miskalî" mahlaslarıla tanınmaktadır. Küçüklüğünden itibaren tarih kitaplarına ilgi gösteren Solak-zâde, Hasodabaşı Hasan Ağa'nın teşvikiyle yazdı̆̆ı ve kendi adıyla meşhur Nevadirü'l Vukū isimli eserin de müellifidir. Osmanlı Devleti'nin kuruluşundan Sultan I. Ahmed'in vefatına kadar gerçekleşen askeri ve siyasi olayları ihtiva eden Solak-zâde Tarihi, Hoca Sadeddin Efendi'nin Tacü't Tevârih'i, Gelibolulu Mustafa Ali'nin Künhü’l Ahbar'1 ve Edirneli Mehmed b. Mehmed'in Nuhbetü't Tevârîh isimli eserlerinin icmalidir. Müellif kaynaklarıı hiç değiştirmeden aynen aktardığından orjinallikten uzak olan eser, Joseph Von Hammer tarafindan Osmanlı Tarihi hakkında yazılmış en faydalı hülasa olarak nitelendirilmiştir.

Anahtar Kelimeler: Solak-zâde Tarihi, Solakzâde Mehmed Hemdemî Çelebi, Hemdemî, Miskalî, IV. Murad, Sadeddin Efendi.
Abstract
Solak-zâde Mehmed Hemdemî Çelebi is a historian, poet and composer who lived in İstanbul in the 17th century. Solak-zâde whom we have little information about is known for pseudonyms such as "Hemdemî" in his poetry and "Miskalî" in music. Solak-zâde, who was interested in history since childhood, is the author of Nevadirü'l Vukū' which he wrote with the encouragement of the concierge Hasan Ağa. The history of Solak-zâde, which includes military and political incidents starting from the foundation of the Ottoman Empire until the death of Sultan Ahmet I, is a kind of synopsis of Hoca Sadeddin Efendi's Tacü’t Tevârih, Künhü'l Ahbar of Mustafa Ali from Gallipoli and Nuhbetü't Tevârîh of Mehmed b. Mehmed from Edirne. The work, which is far from authenticity because the author narrated his resources without changing them, has been described by Joseph Von Hammer as the most useful summary on the history of the Ottoman Empire.

Key Words: History of Solak-zâde, Solak-zâde Mehmed Hemdemî Çelebi, Hemdemî, Miskalî, IV. Murad, Sadeddin Efendi.

\footnotetext{
* Bu makale Solak-zâde Tarihi’nin Tahlili ve Metin Tenkidi isimli doktora tezinden üretilmiştir.
} 


\section{Solak-Zâde Mehmed Hemdemî Çelebi'nin Hayatı}

Solak-zâde Mehmed Hemdemî Çelebi, 17. yüzyılın ilk yarısında İstanbul'da yaşamış tarihçi, şair ve bestekârdır. Doğum tarihi kesin olarak bilinmemekle birlikte 1000 (1591/1592) yılında doğduğu tahmin edilmektedir (Özergin 2009: 749). Babas1 Solakbaşı olduğu için Solak-zâde olarak anıldığı gibi şiirlerinde arkadaş, hem-sohbet anlamlarına gelen "Hemdemî" mahlasıyla, mûsikide ise "Miskalî" mahlasıyla tanınmaktadır (Mehmed Cemaleddin 2003:47; Mustafa Safayî 2005:713-714). Eserlerinde hayatı ve ailesinden bahsetmediğinden hakkında çok az bilgi bulunmaktadır. $\mathrm{Bu}$ sebeple kendisiyle ilgili bilgiler genellikle tahminlere dayanmaktadır. Babasının padişah muhafızı (solakbaşı) olması sayesinde çocukluğu ve gençlik yılları saray ve çevresinde geçen Mehmed Hemdemî, Enderun'da eğitim almıştır (Özcan 2009:370; Yeni Türk Ansiklopedisi 1985:3639). Evliya Çelebi'nin, Seyahatname isimli eserinde, Solakzâde'nin gece-gündüz IV. Murad'ın huzurunda bulunduğundan bahsetmesi ve Hasoda başı Hasan Ağa'ya olan yakınlı̆̆ sarayda önemli bir vazifede bulunduğunu düşündürmektedir (Evliya Çelebi 1314:I; Özergin 2009:749). Nitekim bazı kaynaklarda onun Hasoda Zabitliği’ne kadar yükseldiği ileri sürülmektedir (Büyük Larousse Sözlük ve Ansiklopedisi: 10638). Sultan IV. Murad'ın vefatından sonra da saraydaki görevine devam eden Solak-zâde Sultan İbrahim, Hatice Turhan Sultan ve IV. Mehmed tarafindan da himaye edilmiştir (Yeni Türk Ansiklopedisi 1985:3639; Özcan 2009:370). Bazen çağdaşı olan ve Evliya Çelebi'nin "müsavvirlerin ser-çeşmesi” olarak nitelendirdiği yeniçeri ocağına mensup ve Kalekapısı Mezarlığı'nda medfun Miskalî Solak-zâde Nakkaş Behzad'la karıştırılarak kendisinin nakkaşlık yönü olabileceği ileri sürülse de bu konuda başka bir bilgi bulunmamaktadır (Buttanrı 2001: 36-37; Özcan 2009:370; Özergin 2009:749).

Solak-zâde Mehmed Hemdemî Çelebi 1068 (1657/1658) y1lında vefat etmiştir (Mustafa Safayî 2005:713-714). Silivrikapısı'nda Seyyid Nizam Dergâhı'na giden caddenin sağ tarafinda Çeşmebaşı denilen kahvehanenin köşesinde defnedilmiştir (Bursal1 Mehmet Tahir 1342: 81).

\section{A. Eserleri}

\section{Divan}

17. yüzyılın önemli şairlerinden olan ve Hemdemî mahlasıyla tanınan Solakzâde'nin bir divanı olduğu bilinse de eser günümüze ulaşmamıştır (Özergin 2009: 749).

\section{Fihrist -i Şâhân}

Osmanlı Devleti'nin kuruluşundan IV. Murad dönemine kadar tahta geçen padişahların cülus tarihleri ve saltanatları sırasında gerçekleşen önemli siyasi olayları manzum olarak anlattığ "Fihrist-i Şâhân" adıyla bilinen eserin de müellifidir. Müellif Fihrist-i Şâhân'1, Osmanlı Tarihi'nin herkes tarafından bilinmesi amacıyla telif etmiştir (Solak-zâde AF15:1/b).

Solak-zâde Tarihi'ne dîbâce olarak eklenen Fihrist-i Şâhân manzumesi Vak'anüvis Reşid Efendi ve Münif Paşa, Üsküdarlı Sırrı, Said Paşa, Lebîb Efendi, Derviş Mülhemî Efendi, Nazîrâ İbrahim Efendi, Müstakimzâde Süleyman Sâdeddin Efendi ve 
Ziya Paşa tarafından zeyiller yapılmak suretiyle Sultan Abdulaziz dönemine kadar getirilmiştir (Bursalı Mehmet Tahir 1342: 81; Özcan 2009: 370).

Fihrist -i Şâhân'a ait nüshalar;

Çorum Hasan Paşa İl Halk Kütüphanesi (19 Hk 3234/2), Manisa İl Halk Kütüphanesi (45 Hk 1403), Ankara Adnan Ötüken İl Halk Kütüphanesi (06 Hk 469/2), Mısır Milli Kütüphanesi (Mecâmi Türkî Talat 127 ve Mecâmi Türkî Talat 77 ve Edebi Türkî Talat 155 ve Mecâmi Türkî Talat 140), Ali Emirî Efendi Manzum eserler (Millet Ktb. No. 1318), Esad Efendi (Süleymaniye Ktb. No. 3612/16), Nafiz Paşa (Süleymaniye Ktb. No. 1183), Hüsrev Paşa (Süleymaniye Ktb. 327/2), Köprülü Kütüphanesi Türkçe Yazmaları (415/2) (www.yazmalar.gov.tr).

\section{Besteleri}

Döneminin önemli bestekârlarındandır. Mûsikide Miskalî unvanıyla ün yapmıştır (Mehmed Süreyya 1996: 171). Muhayyer ve rast makamlarında besteleri bulunmaktadır (Özkan 2006:23; Özkan 2007:462). Miskalî olarak anılmasında Miskal adı verilen nefesli çalgının mucidi olması (Güftî 2001:243) ve bu çalgıyı başarıyla icra etmesi etkili olmuştur. Baharistan isimli hüseynî peşrevi, uşşak peşrevi, nevâ peşrevi, nişâbûr peşrevi, segâh peşrevi, nikriz peşrevi, rast peşrev, acem peşrev, eviç saz semâisi ve iki adet mahur şarkının aralarında bulunduğu, bazıları mehteran tarafindan icra edilen, yirmi dokuz adet peşrev ve altı adet saz semaisinin bulunduğu bilinmektedir. Bu bestelerinden başka notası bulunmayan altı peşrevi daha vardır (Özergin 2009:750). Müzik alanındaki bu üretkenliği onun önemli saz bestekarlarından birisi olduğunu gösterir. Güfteli eserlerinden hiçbirisinin notası günümüze ulaşmamıştır (Özcan 2009:370; Yeni Türkiye Ansiklopedisi 1985:3639). Ayrıca Türk Müziğinde "Birleşik Makam" olarak bilinen makamın da mucididir. Bestecilikteki mahareti sayesinde IV. Murad tarafindan himaye ve teşvik görmüştür (Kuruçay ve Dereli 2012:119-120).

\section{Nevâdirü'l Vukū' (Solak-zâde Tarihi)}

a. Eserin İsmi, Telif Sebebi ve Telif Tarihi

Solak-zâde Mehmed Hemdemî eserinde hayatıyla ilgili herhangi bir bilgi vermediği gibi eserinin ismi konusuna da değinmemiştir. Bununla birlikte eser genellikle müellifin adına nisbetle Solak-zâde Tarihi olarak anılmıştır. Ancak Avusturya Milli Kütüphanesi A.F.15 (472) arşiv numaralı nüshanın 282/a nüshasında eserin adı Nevâdirü'l Vukū' olarak geçmektedir. Bu ayrıntı esere ait diğer nüshaların hiç birisinde yer almamaktadır.

Kendi ifadesiyle çocukluğundan itibaren tarih kitaplarına ilgi gösteren müellif, Osmanlı padişahlarının uğurlu zamanlarında gerçekleşen olayları ve garip vakaları kaleme alarak alemde bir eser koymak ve bu sayede haşre dek hatırlanmak arzusunu taşımıştır. Ancak geçen zamanla birlikte zihninin perişan hale gelmesi sebebiyle bu amacını biraz ihmal etse de melek huylu ve cömert bir zât olarak nitelendirdiği Hasodabaşı Hasan Ağanın teşvikiyle Solak-zâde Tarihi adıyla meşhur Nevâdirü'l Vukū' isimli eserini kaleme almıştır (Solak-zâde AF15:1/b). Bazı kaynaklarda bu telife girişmesinde padişah tarafından Hoca Sadeddin Efendi'nin Tacü't Tevârîh isimli eserini 
icmal etmekle görevlendirilmesinin etkili olduğu belirtilmektedir (Özcan 2009:370; Güftî 2001:244).

Eserin müsveddesi durumunda olan Avusturya Milli Kütüphanesi A.F.15 (472) arşiv numaralı nüshanın 236/b nüshasında eserin telif tarihinin 1037 (1627/1628) olduğu belirtilmiştir.

\section{b. Eserin Muhtevası}

Nevâdirü'l Vukū' Osmanlı Devleti'nin kuruluşundan başlasa da bitişi nüshalara göre farklılık göstermektedir. Konuyla ilgili diğer kaynaklarda da eserin bitişiyle ilgili ortak bir kanaat yoktur. Bursalı Mehmed Tahir Bey, eserin Kanuni Sultan Süleyman dönemine kadar geldiğini bildirirken (Bursalı Mehmed Tahir 1342:80) Zeki Velidi TOGAN'a göre eser 1053 (1643) yllına kadar, Nezihi AYKUT'a göre ise 1067 (1657)'ye kadar gerçekleşen olayları ihtiva etmektedir (Hüseyin Tugi 2010: CXXXVI; Togan 1950:208). Eserin bitişiyle ilgili bu belirsizliğin sebebi müellifi tarafindan tamamlanamamış olmasından kaynaklanabilir. Franz BABİNGER, Nevâdirü'l Vukū'ya ait nüshalar arasındaki farklılığın sebebinin nüshaların farklı kişiler tarafindan tamamlanmış olmasından kaynaklanabileceğini ve bu sebeple eserin tam olarak hangi döneme kadar geldiğinin anlaşılamayacağını ifade etmektedir (Babinger 1982:223).

Çalışmamızın temelini oluşturan Avusturya Milli Kütüphanesindeki A.F.15 arşiv numaralı nüshaya göre eser, Osmanlıların atası olan Kayıhan Kabilesi'nin Anadoluya göçü ile başlayıp Sultan I. Ahmed'in vefatına kadar gerçekleşen siyasi ve askeri olayları ihtiva etmektedir.

\section{c. Esere Ait Nüshalar}

Solak-zâde Mehmed Hemdemî Çelebi'nin kaleme aldığı, Nevadirü’l Vukū isimli Osmanlı Tarihi'ne ait eseri, döneminin en kıymetli çalışmaları arasında yer almaktadır. Merhûm Solak-zâde'nin şiir sanatındaki maharetinin yansımalarıyla dolu olan eserin yurt içinde ve yurt dışında birçok nüshası mevcuttur. Bu nüshalar arasında bulunan Avusturya Milli Kütüphanesinde A.F.15 (472) numaralı nüsha eserin tespit edilebilen en eski nüshası olması bakımından önem taşımaktadır. Ayrıca nüshanın derkenarlarında yazılı bulunan "Câmi' -i Ahmed Hanın evvel Cum'a namazı mâh-ı şa'bânın evâsıtında kilındl. Şeyh Kutbü'l Ârifin kılmışlardır ki Üsküdarî Mahmud Efendi yadigârıdır işitdigin yaz" (358/a) ve 359/b varağındaki "Sultân Ahmed merhûmun salat-ı cenazesi Üsküdarl Kutbü'l Arifin Şeyh Mahmud Efendi kalmışdır. Müverrih bu irâde-i hakikat hali tefehhüs eyledigin yazmış" (359/b) ifadelerden bu nüshanın müellife ait müsvedde olduğu anlaşılmaktadır. Ayrıca nüshanın 172/b, 175/a ve 180/b varaklarının kenarlarında latin harfleriyle yazılmış ve silik olduğu için okunamayan birtakım notlar bulunmaktadır.

İki kısımdan oluşan nüshanın birinci kısımı kuruluştan Sultan III. Murat dönemi sonuna kadar gerçekleşmiş olayları ihtiva etmektedir. Bu kısımın 217/b varağında Şehzade Bayezid'in Acem Şahı Tahmasb'ın yanına sığınma olayı anlatılırken konu yarıda kesilerek 956 (1549) yılındaki Gürcistan Seferinden itibaren vuku bulan olaylar farklı bir üslupla tekrar ele alınmıştır. İkinci kısımda ise "Tevârîh -i Âl-i Osmân Fâtih-i Egri Sultân Muhammed Han Müellif Solâk-zâde Nevâdirü'l Vukū" başlığı altında Sultân III. Mehmed ve I. Ahmed dönemlerini anlatmaktadır. 
Esere ait diğer nüshalar Kanuni Sultan Süleyman'ın vefatına kadar Nevâdirü'l Vukū' adlı eserin temize çeklmiş haliyle Hasanbeyzâde Tarih'lerinin birleştirilmiş halidir. Bu sebeple A.F.15 (472) arşiv numaralı nüsha dışındaki nüshalar Solak-zâde Tarihi hakkında yeterli bilgi vermemektedir.

\begin{tabular}{|l|l|l|}
\hline Yurt Dışında Bulunan Nüshalar & Arşiv Numaras1 & Varak Sayıs1 \\
\hline Bulunduğu Yer & A.F.15 (472) & 359 \\
\hline Avusturya Milli Kütüphanesi & H.O.21 & 179 \\
\hline Avusturya Milli Kütüphanesi & Hs.or.1105 & 554 \\
\hline Almanya Milli Kütüphanesi & Ms.or.qu.1663 & 240 \\
\hline Almanya Milli Kütüphanesi & Tarih-i Türkî 413 & 494 \\
\hline Misır Milli Kütüphanesi & 6038 & 361 \\
\hline Misır Milli Kütüphanesi & Tarih-i Türkî 140 & 361 \\
\hline Misır Milli Kütüphanesi & Regius 1297-6 & 314 \\
\hline Fransa Milli Kütüphanesi &
\end{tabular}

\begin{tabular}{|l|l|l|}
\hline Yurtiçinde Bulunan Nüshalar & Arşiv Numaras1 & Varak Sayıs1 \\
\hline Bulunduğu Yer & 3138 & 440 \\
\hline Süleymaniye Kütüphanesi (Nuruosmaniye) & 3137 & 440 \\
\hline Süleymaniye Kütüphanesi (Nuruosmaniye) & 225 & 250 \\
\hline Süleymaniye Kütüphanesi (Hafid Efendi) & 906 & 306 \\
\hline Süleymaniye Kütüphanesi (Hamidiye) & 604 & 382 \\
\hline Süleymaniye Kütüphanesi (Halet Efendi) & 302 & 472 \\
\hline Süleymaniye Kütüphanesi (Mihrişâh Sultan) & B.199 & 382 \\
\hline Topkapı Sarayı Müzesi Kütüphanesi & R.1102 & 103 \\
\hline Topkapı Sarayı Müzesi Kütüphanesi & A.3078 & 490 \\
\hline Topkapı Sarayı Müzesi Kütüphanesi & & \\
\hline
\end{tabular}

Esere ait el yazması eserlerin yanında 1298 tarihinde İstanbul Mahmud Bey Matbaasında basılmış 773 sayfadan oluşan matbu nüsha ile 1271 tarihinde basılan ve 83 sayfadan oluşan taşbasması nüshalar da bulunmaktadır.

\section{d. Solak-zâde'nin Kaynakları}

Solak-zâde Tarihi'nin kaynaklarıyla ilgili yapılan değerlendirmelerde eserin kuruluştan Kanuni Sultan Süleyman dönemine kadar Hoca Sadeddin Efendi'nin Tacü't Tevârîhi'ni (Togan 1950:208) ve Kanuni Sultan Süleyman'ın vefatından sonrası için Hasan Beyzâde Tarihi'nin hiç değiştirilmeden kullanıldığı fikri hâkimdir. M. Cavit BAYSUN, Solak-zâde'nin Hasan Beyzâde Tarihini hiçbir değişiklik yapmadan naklettiğini ileri sürmüştür (Baysun 1953:321; Arıkan 2011:69). Prof. Dr. Nezihi AYKUT'da M. Cavit BAYSUN'la aynı fikirde olmakla birlikte Solak-zâde'nin Hasan Beyzâde Tarihi'nin muhtevasını kısaltma veya değiştirmeye lüzum görmeden ilgili kısımları kendisine mal ederek aynen aktardığı düşüncesindedir (Hasan Beyzâde 2004: CCCLXXXVII). Yine AYKUT'a göre II. Osman ve I. Mustafa'nın ikinci saltanat dönemi için Solak-zâde Tarihi'nin başlıca kaynağı Hüseyin Tugi'nin Musibetnâme adlı eseridir (Hüseyin Tugi 2010: CXXXVI). Vahid ÇABUK, Solak-zâde'nin eserinin son kısmında bizzat görgü tanığı olduğu olaylanı aktardığını ileri sürmüşse de (Çabuk 
1989:VI) bunun doğru olmadığı, Solak-zâde Tarihi'nin son kısmının Vecihi Tarihi'nden eklendiği ve bu kısmın sanıldığı gibi orjinal olmadığı görülmektedir (Afyoncu 2007:64).

Solak-zâde Tarihi'nin kaynakları konusunda yukarıda bahsedilen görüşlerin temelinde eserle ilgili daha önce yapılan çalışmalada Topkapı Sarayı Müzesi Kütüphanesi'ndeki A.3078 arşiv numaralı nüshanın esas alınması ve eserin yurt dışındaki nüshalarının incelenmemiş olması yatmaktadır. Topkapı Sarayı Müzesi Kütüphanesi A.3078 arşiv numaralı nüshayla birlikte Nuruosmaniye 3138 ve 3137 arşiv numaralı ve Hamidiye (Murad Molla Ktb.) 906 arşiv numaralı ve Haletefendi 604 arşiv numaralı ve Fransa Milli Kütüphanesi Regius, 1297/6 arşiv numaralı ve Avusturya Milli Kütüphanesinde bulunan H.O.21 arşiv numaralı nüshalarada Kanuni Sultan Süleyman döneminin sonundan itibaren Hasan Beyzâde Tarihi aynen yer almaktadır. Ancak Nuruosmaniye 3138 arşiv numaralı nüsha ve Avusturya Milli Kütüphanesi H.O.21 arşiv numaralı nüshalarda bulunan derkenârlarda yer alan ifadelerden anlaşıldığına göre, Hasan Beyzâde Tarihi Solak-zâde Tarihi'ne müellifin vefatından sonra eseri istinsah eden müstensihler tarafindan eklenmiştir ${ }^{1}$.

Solak-zâde Mehmed Hemdemî eserinde kaynak olarak 15 ve 16. yüzyılda tarih alanında kıymetli eserler vücuda getirmiş olan Mevlânâ Ruhi, Şerefeddin 'Âlî Yezdî, Molla Hamza, Mustafa bin Celâl Tevkî, Müneccimbaşı Ahmed, Mevlânâ Mehmed Neşrî, Âşıkpaşazâde, İdrîs -i Bitlisî, İbrahim Peçevî, Rumîlî Kadıaskeri Hamid Efendi, Seydi Ali Çelebi, Şair Sami Bey, Şems Ahmed Ağa ve Yahya Bey'in eserlerinin isimlerini zikr etse de aslında bu kaynakları kendisi kullanmamış, eserini hazırlarken neredeyse aynen aktardığı Hoca Sadeddin Efendi'nin Tacü’t Tevârîhi, Gelibolulu Mustafa Ali'nin Künhü'l Ahbârı ve Nusret-nâmesi ile Edirneli Mehmed bin Mehmed (Er Rumî)'in Nuhbetü’t Tevârîhi'nin kaynaklarını kendi kaynakları gibi göstermiştir.

Gelibolulu Mustafa Ali'nin Künhü'l Ahbârı'ndan da önemli bir ölçüde faydalanan Solak-zâde'nin II. Selim, III. Murad, III. Mehmed ve I. Ahmed dönemleri için kaynağı Edirneli Mehmed bin Mehmed (Er Rumî)'in Nuhbetü't Tevârîh adlı eseridir. Müellif ayrıca sınırlı olmakla birlikte Selânik'i Tarihi'nden de faydalanmıştır.

\section{Tacü’t Tevârih'in Kaynak Olarak Kullanımına Ait Örnekler}

Solak-zâde Tarihi Yavuz Sultan Selim dönemi sonuna kadar Hoca Sadeddin Efendi'nin Tacü't Tevârîh adlı eserinin sadeleştirilmiş ve kısmen özetlenmiş halinden başka bir şey değildir (Togan 1950:208). Konuların kronolojik aktarımı dahi Tacü’t Tevârîh'le aynıdır. O, Sadeddin Efendi'nin kaynaklarla ilgili yaptığı tenkitleri kendi düşünceleri gibi aktarmaktan çekinmemiştir. Solak-zâde'nin Sadeddin Efendi'nin eserini bu şekilde kullanmasında padişah tarafindan Tacü't Tevârîh'i icmal etmekle görevlendirilmesinin önemli bir rolü bulunmaktadır (Özcan 2009:370). Solak-zâde

\footnotetext{
${ }^{1}$ Solak-zâde Tarihi, Nuruosmaniye Kütüphanesi 3138, varak no: 316/A "Bu mahalle gelince Solâkzâde merhûmun müsveddesinden beyâz olunup aşagısı Kânije Fethinde tezkirecilik hidmetinden sonra Reisü'l küttâb olan Hasan Begzâde nam kimesnenin tahrîr eyledigi tarihden tahrîr olunmuşdur.", Solak - zâde Tarihi, Avusturya Milli Kütüphanesi H.O.21, varak no: 132/b: "Bu mahalle gelince istinsâh eyledigimiz nüsha Solâkzâde merhûmun kendi müsveddesinden beyâz edüp bundan sonra Kânije Fethinde tezkirecilik hidmetinden Reisü'l küttâb olan Hasan Begzâde'nin tevârîhden tahrîr etmekle biz dahi öylece istinsâh etdik ma 'lûm oluna."
} 
Mehmed Hemdemi Çelebi Hoca Sadeddin Efendi'nin Tacü't Tevârîh'ini kullanırken kaynağına atıf yapmaksızın muhtevayı aynen aktarma yoluna gitmiştir.

\section{Solâk-zâde Tarihi}

$\mathrm{Bu}$ tas sernîgûn olmaz cefầdan bir nefes hali / Gönül verme ana ey akıl anın böyledir hali (Nesr) Hâlen Sazlıdere'de türbesi mâ'lûmdür. Merhûmun Bursa'da mescidi ve medresesi vardır. Ve Bursa Hisârı'nda mescid ve medresesi ve imâreti olan İsâ Beg anın ferzend-i sûlbiyesidir. Bâyezîd Pâşâ'nın şehâdetinden mukaddem İzmiroglu Cüneyd Beg dahi müte'allikatı ile Düzme yanına varmış idi. Ana dahi pâye-i vezâretle ri'âyet olunup hayli iltifâta mazhar düşdü. Ve Rumili'nin yayasını müsellem edüp biri birine harçlıkcı eylemek anın tedbîri ile Düzme eyyâmında peydâ olmuşdur. Ve hem hadden ziyâde sipâh ve piyâde ki azab demekle ma'rûfdur... A.F.15/51/b

\section{Tacü’t Tevârîh}

$\mathrm{Bu}$ tas sernîgûn olmaz cefâdan bir nefes hali / Gönül verme ana ey akıl anın böyledir hali. Merhûmun Bursa'da mescidi ve medresesi vardır. Ve Bursa Hisârı'nda mescid ve medresesi ve imâreti olan İsâ Beg anın ferzend-i sûlbiyesidir. Bâyezîd Paşa'nın şehâdetinden esbak İzmiroglu Cüneyd Beg dahi a'vânı ile Düzme yanına varmış idi ve ol dahi pâye-i vezâret rütbesine erişmiş idi ve Rumili'nin yayasını müsellem ba'zını ba'zına harçlıkcı eyleyüp ellişer akça vermek anın tedbîri ile Düzme eyyâmında peydâ olmuşdur. Ve hem hadden ziyâde sipâh ve piyâde ki azab demekle ma'rûfdur cem' etdiler.

Tacü’t Tevârîh, Matbaa -i Amire, İstanbul 1862, s: 308

\section{Solak-zâde Tarihi}

Karamanoglu vefât edicek Pîr Ahmed Beg Konya'da mesned nişîn olup büyük biraderi İshak Beg Konya tahtgâhından dûr ve hükûmetini İçili'ne mahsûr eyledi. Süleyman ile Nûre Sofî Sultân Muhammed Hân asitânesine ilticâ edüp mahsûldâr-1 tîmârlar ile ri'âyet olundular. İshak Beg da'vâ-yı istihkāk ederken pederi hükûmetinden dûr olduguna bî huzûr olup Uzûn Hasan'a mürâca'at nâme gönderüp biraderi elinden Karaman tahtını tahlîse imdâd-ı recâ eyledi. Ve imdâd içün asker gönderdigi takdirce her merhalesine bin sikke hasene vermegi ta'ahhüd ve iltizâm eyledi. Uzûn Hasan İshak Beg'in peygâmın ve filori nâmın işidecek tama'a düşüp Erzincan yolundan Sivas'a geldikde İshak Beg istikbâl idüp Karaman diyârına getirdi. Pîr Ahmed Beg anlarla mukābeleye kadir olmayacagını bilüp birâderleri ile şâh-1 âlîcenâb dergâhına şitâb edüp...

\section{A.F.15/83/b}

\section{Tacü’t Tevârîh}

Karamanoglu'nun besât-1 hayatı tayy olacak oglu Pîr Ahmed Beg Konya'da mesned nişîn olup İshak Begi (okunmuyor) tahtgâhından dûr ve eyaletgâhını İçili'ne mahsûr eyledi. Süleymân ile Nûre Sofî Sultân Muhammed Hân Gāzi asitânesine ilticâ ile karîn-i ser ferâzı olup mahsüldâr-1 tîmâr ile ri'âyet olundular. İshak da'vâ-yı istihkāk eder iken pederi tahtgâhından dûr olduguna bî huzûr olup Hasan-1 Dırâz dâmenine teşebbüs etmege agâz edüp hedâya ile darâ'at nâme gönderüp biraderleri elinden Karaman 
tahtgâhını tahlîse dermân istedi. Ve imdâd içün sevk-i ecnâd etdigi takdirce ücret-i kadem her merhalesine bin filori vermegi iltizâm eyledi. Hasan-1 Dırâz dahi İshak Beg'in peygâmın ve filori nâmın gûş edecek deryâ-yı tama'ı hurûş edüp hemândem râh-1 Erzincan'dan Sivas'a geldi. İshak Beg dahi Hasan-1 tavîl istikbalinde te'cîl edüp envâ'-1 tebcîl ile Vilâyet -i Karaman'a getirdi. Pîr Ahmed'in ol gürûh-i anbûh ile mukāvemete iktidârı olmadıg1 cihetden biraderleri ile şâh-1 valâ cenâb dergâhına şitâb edüp...

Tacü’t Tevârîh, Matbaa -i Amire, İstanbul 1862, s: 499

\section{Künhü'l Ahbâr'ın Kaynak Olarak Kullanımına Ait Örnekler Solâk-zâde Tarihi}

Künhü'l Ahbâr sâhibi merhûm Ali Efendi yazdıg1 üzre bu dahi meşhûr ba'z1 tevârîhde mestûr ve'l sine-i nâsda mezkûrdur ki Bursa halkı leşker-i Tâtâr gāretinden makhûr ve nice vechile müte'ellim ve me'sûr olduklarında ol zamanda kutb-i âlem olan Emîr Sultân Hazretleri'ne vardılar. Timur leşkerini bu diyârdan def edüp bizi mazarratlarından kurtarın diyü yalvardılar. Anlar dahi mürîdlerinden birine işâret idüp Timur Hân ordusuna gönderir felân na'lbandı bulup bizden selâm eyle. Ba'del veym ahar diyâra teveccüh buyurmaları mercûddur. Benim lisânımdan söyle diyü vasiyyet ederler. Vaktâ ki ol mürîd şahıs na'lbanda varır. Emîr Sultân'ın kelâmını nakl kılup i'lâm edince na'lband-1 mezbûr nola hatırları içün kalkalım diyü buyurur. Hemân na'lbandlıga müte'allik olan aletini devşirüp hazır olunca anı görürler ki Asker-i Timur birbirine bakmayup çekilüp giderler. Acem Diyârına dogru azîmet ederler... A.F.15/33/a-33/b

\section{Künhü'l Ahbâr}

Bu dahi meşhurdur ki Bursa halkı leşker-i Tâtâr gâretinden makhûr ve nîçe vechle müte'ellim ve me'sûr olduklarında ol zamânda gavs-1 rüzgâr olan Emîr Sultân'a varırlar. Timur leşkerini bu diyârdan def" edüp bizi mazarratlarından kurtarın diyü yalvardılar. Anlar dahi mürîdlerinden birine işâret edüp Timur Hân ordusuna gönderdiler. Falân na'lbandı bulup bizden arz-1 selâm eyle. Bugünden sonra ahar diyâra teveccüh buyurmaları mercûddur diyü benim lisânımdan söyle diyü vasiyyet ederler. Vaktâ ki ol mürîd na'lbanda varırlar Emîr Sultân'ın kelâmını nakl edüp hatırları içün kalkalım diyü buyurur. Hemân na'lbandliga müte'allik olan aletini devşirir. Anı görürler ki Asker-i Timur birbirine bakmayup çekilüp giderler. Acem Diyârı'na dogru azimet ederler...

Künhül Ahbâr, TTK Tipkibasım, Ankara 2009, varak: 35/B

\section{Solâk-zâde Tarihi}

Ammâ Câmi ‘ü'l Meknûnât nâm kitapda ve Ahmedî karındaşı Molla Hamza'nın târîhinde yazar ki Yıldırım Hân'ın ahz olundugu gün Timur'un huzûruna getirdiklerinde envâ‘ i'zâz ile istikbâl idüp bir mesned üzre ikisi iclâs eylediler. Bâ'de'l mükaleme fermân-1 Timur ile önlerine ta'âm içün sofra geldi. İbtidâ ortaya bir kâse ile yogurd konuldu. Yıldırım Hân yogurdu görünce ta'accüb künân hayrete varup bir zamân düşündü. Timur Hân bâ‘ is fikriniz nedir diyü istihbâr kıldıkda etdi ki mukaddemâ Sultân Ahmed Celâyir Bagdâdî bize gelüp iltica etmiş idi. Timur Hân'la bizim mülâkātımız bi-lahare neye müncerr olur bu niyet üzre bir remil eyle diyü iltimâs eyledim. Önüne tahta remilin koyup eşkāl-i tarh eyledi. Ve birâz fikre varup sakalın sıgadı durdu. Ba'dehu baş 
kaldırup etdi ki gâybın Allah bilir ammâ âkıbet ikiniz bir yere gelüp önünüze sofra konuldukda evvel gelecek ta'âm kâse ile yogurd olacakdır. Hâlen anın ilmini tasavvur ederim... A.F.15/29/b

\section{Künhü'l Ahbâr}

Ammâ Câmi'ử'l Meknûnât nâm kitapda ve Ahmedî karındaşı Molla Hamza'nın târîhinde yazılmışdır ki ol şeb ki Timur'un meclisine Sultân Bâyezîd'i getirdiler. Ba'de'l iclâl huzûruna sofra yaturdular ki ol konulan ta'âm bir kâse yogurd idi. Bâyezîd Hân ol yogurdu gördükde hayrete varup düşündü. Timur Hân bâ‘is-i fikr-i mevfûr nedir diyü istihbâr kıldıkda cevabında mukaddemâ Sultân Ahmed Celâyir Bagdâdî bezmimizde mühimmâ-1 derviş nihâd iken sizinle mülâkātımız niyyetine reml etmiş idi. Bi-l-ahare ikiniz bir yere gelüp ibtidâ sofranıza gelecek ta'âm yogurd olacakdır diyü söylemiş idi. Hâlen anın ilmini tasavvur ederim.

Künhül Ahbâr, TTK Tıpkıbasım, Ankara 2009, varak: 34 / A

\section{Nusret-nâme'nin Kaynak Olarak Kullanımına Ait Örnekler \\ Solâk-zâde Tarihi}

Diyarbakır Eyâletinden ma'zûl Osman Pâşâ gönderildi. Anlar dahi el-veledü sırrü ebîhi fehvâsınca peder-i zafer rehberi Özdemir Pâşa gibi gûnâ gûn hucûm ve cünbüşler ederek fî-1-hâl neheng-i hevlnâk kenâr-1 deryâ çehde zâhir oldu. Ve sâhile çıkmış hass ü hânnâk misâl rafızı bed girdârı birbirine katup lâşelerin peşte peşte kıldı. Dem oldu ki elindeki şimşiri altındaki semend-i bâd pâsı gibi kanlar feşândı. Mahal düşdü ki tîr-i ejderhâ te'sîri nice sengîn-dilin kalbinde göz göre ateşler çıarup yılanlar kuşandı. A.F. $15 / 251 / \mathrm{a}$

\section{Nusret-nâme}

Diyarbakır'dan münfasıl olan Osman Pâşâ kulları gönderilüp el-veledü sırrü ebîhi fehvâsınca peder-i zafer-rehberi Özdemir Pâşâ merhûm gibi gûnnâ gûn hucûm ve cünbüşler ve nusret-nümûn $u$ fursat-makrûn verzişler ile silahşörlerini tertîb ve semt-i gazâyı her birine ta'lim ve tergib eyleyerek fi-1-hâl neheng-i hevlnâk gibi kenâr-1 deryaçede zâhir oldu ve sâhile çıkmış hâs ü hâşâk gibi revâfız-1 bed-girdârı birbirine katup puşte puşte kıldı. Dem oldu ki elindeki şimşiri altındaki semend-i salâbet-mesîri gibi kanlar kaşendi. Mahal düştü ki tîr-i ejderhâ te'siri nice sengin-i dilin kalbinden göz göre göre ateşler çıkarup yılanlar kuşandı.

Nusret-nâme, Hazırlayan: Mustafa Eravcı, TTK Yayınları, Ankara 2014, s. 100

\section{Nuhbetï’t Tevârîh'in Kaynak Olarak Kullanımına Ait Örnekler Solâk-zâde Tarihi}

Def 'ine nâmzed kılınan Vezir Hüsrev Pâşâ'ya Şam ve Haleb ve Maraş askeri gezend kimse itâ'at etmeyüp ve andan dahi Sivas câniblerinden geldiklerinde şitâ zamânı nihâyete erüp yanından daglatup gitdikleri müfsid-i mezbûrun Engüri'ye semtlerine geldikde mesmû' 1 olmagla ardından bî bâk olup Anadoli muhâfazasından olan sâlifü'z zikr Hâfız Ahmed Pâşâ ile cenk û peykâr niyyetle kalkup Kütahya câniblerine azîmet etdi... A.F.15/315/a 


\section{Nuhbetü't-Tevârîh ve'l-Ahbâr}

Def' ine nâmzed kılınan Vezir Hüsrev Pâşâ'ya Şam ve Haleb ve Maraş askerinden kimse ita'at etmeyüp andan dahi Sivas tarâflarına geldiklerinde şitâ zamanın nihâyete erüp yanından gitdikleri müfsid-i mezbûrun Engüri'ye semtlerine geldiklerinde mesmû' ${ }^{\prime}$ olmagla Edirne'den bî bâk olup Anadoli muhâfazasında olân sâlifü'z zikr Hâfiz Ahmed Pâşâ ile cenk etmek kasdıyla kalkup Kütahya tarâflarına gitdi...

Nuhbetü't-Tevârîh ve'l-Ahbâr, İstanbul 1276, s: 212

\section{Solak-zâde Tarihi}

Ol zaman ki sipâh tâ'ifesinin der devletde cem'iyyetler edüp bâb-1 sa'âdet ve dârü's sa'âde agāsını katl etdiklerinden ve kendinin katli üzre dahi musirr olup ahd ü güft etdiklerin sâlifü'z zikr Vezir-i Azam ve Serdâr Meyveî Hasan Pâşâ ki Belgrad kışlasında işitdi. Bir gün dahi tevekkuf etmeyüp bervech-i ılgār der sa'âdet cânibine teveccüh ve azîmet etdi. Sene ihda aşere ve elf şa 'bânının yigirmi beşinci gününün gicesinde dâhil-i İstanbul olup Atmeydânı'nda zevcesi olan Âişe Sultân dâmet ismetühâ sarâyına ki dâhil oldu...A.F.15/315/a

\section{Nuhbetï't-Tevârîh ve'l-Ahbâr}

Ol zamân ki sipâh tâifesinin der devletde cem'iyyetleri olup bâbü's sa'âde ve dârü's sa'âde agāların katl etdirip kendinin katli içün musirr olup ahd ü güft ü gû etdiklerin sâlifü'z zikr Vezir-i Azam ve Serdâr Yemişci Hasan Pâşâ Belgrad kışlasında işitdikde bir gün dahi tevekkuf kılmayup ılgārla der devlete geldi. Sene ihda aşere ve elf şa ‘bânının yigirmi beşinci gicesinde dâhil-i İstanbul olup Atmeydânı'nda zevcesi Âiş̧e Sultân sarâyına geldi...

Nuhbetü't-Tevârîh ve'l-Ahbâr, İstanbul 1276, s: 213

\section{Solak-zâde Tarihi}

Mâh-1 mezbûrun yigirmi üçüncü günü ki yevm-i Cuma idi. Ol gice Çavuşbaş1 gönderilüp merhûm hüdâvendigâr zamanında Diyarbakır Eyâletinden azl ile Yedikule'de habs olunan Divâne İbrahim Pâşâ ki Harem-i Muhteremde kethüdâ olan Cânfedâ Hâtûn'un karındaşı olup gāyetde zâlim ve seffâk-1 bî bâk ve bî eş̧âk kimesne idi. Boğdurulup zâlimin cezası budur diyü meyyiti Yedikule kurbinde ki deryâya bırakıldı...

A.F.15/283/a

\section{Nuhbetü't-Tevârîh ve'l-Ahbâr}

Mâh-1 mezbûrun yigirmi üçünde Cumartesi gicesinde çavuşbaş1 gönderilüp merhûm hüdâvendigâr zamânında Diyarbekir Eyâletinden azl ile Yedikule'de habs olunan Divâne İbrahim Pâşâ ki Harem-i Muhteremde kethüdâ olan Cânfedâ Hâtûn'un karındaşıydı gâyetde zâlim ve seffâk-ı bî pâk kişiydi. Bogdurulup meyyitin Yedikule kurbindeki deryâya birakdılar.

Nuhbetü't-Tevârîh ve'l-Ahbâr, İstanbul 1276, s: 177. 


\section{Selânikî Tarihi’nin Kaynak Olarak Kullanımına Ait Örnekler Solak-zâde Tarihi}

Târîh-i Hicret-i Nebeviyye Sallallahu Aleyh-i ve Sellemin dokuz yüz yetmiş saferinin rûz-i evvelinde şehriyâr-1 alî vekār hazretleri arzu-yi temâşâ-yı sayd ü şikâr ile Halkalıpınar câniblerine hareket buyurmuşlar idi. Nâgâh cevv-i semâda olan safvet-i kedûrete mütebeddil ve evzâ-1 felekiyye ve etvâr-1 icrâm-1 uluviyye şekl-i ahare mütehavvil olup etrâf ü eknâfda alâmet-i bârân müşâhede kılınmagın leb-i deryâda vâki‘ Mîrî İskender Çelebi bagcasına sür'at -1 âlemi zulmât kaplayup mehâbet üzre yetmiş dört def'a yıldırım inüp...

\section{N.O.3138/307/a}

\section{Selânikî Tarihi}

Târîh-i Hicret-i Nebeviyye Sallallahu Te'âlâ Aleyh-i ve Sellemin sene ihdâ ve seb'in ve tis'ami'edesinde vâki' selh-i muharremü'l harâm ve gurre-i saferü'l muzafferinin dû şehbih gününde seheri pâdişâh-1 âlem penâh Sultân Süleyman Hân eyyede'llâhu saltanatihi hazretleri Halkalıdere etrâfinda şikârgâha teveccüh buyurup etrâf ü eknâfda alâmet-i bârân müşâhede etmegin leb-i deryâda vâki' Ayastefanos denmekle meşhûr karye kurbunda Mîrî İskender Çelebî bagcasına nüzûl ü iclâl buyurduklarında evzâ'-1 felekiyye ve ecrâm-1 ulviyyenin harekâtı bu vechile oldu ki bir devirde ne işidilmiş ve ne görülmüs acîb û mehîb berk-i hâtıf ve sâ’ika âgāz edüp gerdûn gerdân kûm kûm kûmlayup âfâk inlemeye başladı. Ve azîm firtınalar ile bir gün bir gice lâyenkatı' şiddet birle bârân yagup ve şiddet ve mehâbet üzre yetmiş dört def'a yıldırım indi.

Mustafa Selânikî, Selânikî Tarihi, İstanbul, 1281, s: 2-3

\section{B. Müellifin Tarihçiliği}

Nevâdirü'l Vukū' Josheph von Hammer'e göre; “Türkiye Tarihi hakkında yazılmış en faydalı hülasa" olarak nitelendirilse de (Hammer 1999:19) büyük ihtimalle tamamlanamamış olmakla birlikte orijinal bir eser olmaktan uzaktır. Eserde aktarılan olayların çoğusu ana hatlarıyla kendisinden önce yazılmış eserlerde mevcuttur. Eser bu yönüyle bir derleme niteliğindedir. $\mathrm{Bu}$ sebepledir ki eser Solak-zâdenin kendi gözlemlerini ve değerlendirmelerini yansıtması bakımından zengin değildir. Eserinde kaderci bir anlayışı benimseyen Solak-zâde Mehmed Hemdemî Çelebi, kaynak olarak kullandığı eserlerde hanedan üyeleri ve devlet yöneticileri hakkındaki eleştirilerin çoğunu hiç değiştirmeden aktararak dolaylı bir şekilde bu eleştirilere katıldığını göstermiştir. Özellikle Emir Süleyman'1 sabah ve akşam Edirne hamamlarında eğlenceye dalması sebebiyle eleştiren müellif, padişahların halkın ve askerin durumundan haberdar olması gerektiğini vurguladıktan sonra, bu makamın keyfine düşkün ve halktan uzak kimselerin makamı olmadığını ve aksi takdirde memleket işlerinin sıkıntıya gireceğini vurgulamıştır (Nuruosmaniye 3138/53/b). Solak-zâde Mehmed Hemdemî Çelebi kendi dönemindeki padişahları daha önceki padişahları örnek göstererek ilme ve ilim adamlarına karşı tutundukları tavır dolayısıyla da üstü kapalı bir şekilde eleştirme yoluna gitmiştir (A.F.15/69/a). Yıldırım Bayezid döneminde ortaya çıkan usulsüzlükleri eleştiren müellif bu eleştiriyi yaparken Osman Gazi ve Orhan Gazi dönemlerini örnek göstererek bu 
padişahların ulemanın sözünü dinlediğini ve onların görüşlerine önem verdiklerini belirtmiştir (A.F.15/22/a). Müellif Kanuni Sultan Süleyman'1 ise Vezir-i Azam Ahmet Paşa'yı herhangi bir sebep olmamasına rağmen Rüstem Paşa'nın iğvasıyla katlettiği için açikça eleştirmiştir (A.F.15/207/b).

Bazı devlet adamları da müellif tarafından eleştirilmişlerdir. Bunlardan Yıldırım Bayezid'in Vezir-i Azamı olan Ali Paşa'yı padişahı yoldan çıkarmakla ve onu şaraba alıştırmakla (A.F.15/22/a) ve Maktül İbrahim Paşa'yı ise Kanuni Sultan Süleyman'a ihanet etmekle suçlamıştır (A.F.15/189/a).

Solak-zâde bazen isim vererek ve bazen de isim vermeden tarih yazarlarını da eleştirme yoluna gitmiştir. Özellikle Yıldırım Bayezid'in intihar ettiğini anlatan tarihçileri tarih bilmemezlikle, bulduğunu yazmakla ve padişahın şanına layık olmayan iftiraları ona yakıştırmakla itham ederek açıkça eleştirmiştir (A.F.15/33/b).

Olayları anlatırken kaderci bir anlayış benimsemiş olan Solak-zâde ${ }^{2}$ bazen de hurafelere yer vererek anlatımını zenginleştirme yolunu seçmiştir. Sultan I. Murad'ın elindeki doğanın elinden uçarak bir camiinin kubbesine konduğunu ve bu durumdan rahatsız olan I. Murad'ın doğana "kuruyu kal" dediğini ve bunun üzerine kuşun olduğu yerde kuruduğunu ve kendisinin kuşun cesedini 1030 tarihinde Bursa'da bulunduğu bir sırada gördüğünü belirttikten sonra "görmesem inanmazdım. Uçurtma sanardım" diyerek bu olay karşısındaki hayretini ifade etmiştir (A.F.15/19/b).

\title{
C. Müellifin Üslubu
}

Solak-zâde Tarihi dil açısından çağdaşlarına pek benzememektedir. Oldukça sade bir Türkçeyle kaleme alınan eserde süslü ve uzun ifadelere yer verilmediği, gündelik konuşma diline yakın bir dil kullanıldığı görülmektedir.

\author{
Manayı Kuvvetlendirmek İçin Nesirde Kullandığı Kafiyeler \\ fakir kâlîl-ül-bizâ 'a ve adimü'l istitâ'a \\ vakāyi 'i garibe ve nevâdir-i acîbe \\ kaleme getürüp cem 'idem ve bende alâ külli hâl âlemde bir eser koyam gidem \\ bu abd-i nâ-tuvân takallüt-i ahvâl-i rüzgâr ile biraz perişân \\ ol kerîmü'ş-şânin ve ol mürebbî-i erbâb-ı irfânın \\ mazhar-ı ihsanları ve şeb $\hat{u}$ rûz senâ-hânları \\ bu vechle ayân ve bu uslûb üzre takrîr û beyân \\ kimi seyrâncı kimi temâşacı
}

\footnotetext{
2 “...Hakīkat hâl nazar etsen insân dedigi olmaz Hak dedigi olur...” (A.F.15/214/a) “...Kassâm ü kazâ ve kader cihân iki birâder miyânında berâber taksîm edüp tahta-ı tâbûtu Cem'e ve taht-l şâhiyi sultān-ı ferhundeye dame ta'yîn eylemiş. Beyt: Alan oldur veren oldur, Eden ol etdiren ol, Yâ bu insan-l za'ylf etdigi tedbîr nedir...” (A.F.15/107/b), “...Nesr: Nitekim ol devrin şu'arâsından birisi mahalle münâsib bu gûna bir kıt'a demişdir. Klt'a: Çün be hükm-i Kadir-i Kayyûm Kassâm-ı ezel, Tahtla tâhta-ı tâbûtu taksîm etdiler, Bahtı gör kim tahta-i tâbûta verdi Bâyezîd, Tahtı bir Şâh-ı Selîmü't tab 'a teslîm etdiler...” (N.O.3138/306/b)
} 


\section{Manayı Kuvvetlendirmek İçin Kullandığı Eşanlamlı Kelimeler}

Irz u nâmûs, âbâ u ecdâd, adl u dâd, ahd u misâk, ahd u şurût, bâr u büngâh, bihadd u lâ-yu'add, bî-hadd ve bî-hesab, bî-hadd ve bi-payân, bi-hadd ve bi-şümâr, burc u bârû, gâm u elem, garet u hasâret, gavs u feryâd, gayret ve hamiyet, gazâ ve cihâd, güft $\ddot{u}$ gû, halisen ve muhlisen, harb ü kitâl, havf ü haşyet, hâzur ve âmâde, hâzır ve müheyya, heybet ve salâbet, hûy u hây, hüsn ü cemâl, i'zâz ü ikrâm, ihmâl ü tekâsül, in'âm ü ihsân, inklyâd ü ita'at, izz ü câh, kaht ü galâ, kīl ü kāl, kuvvet ü kudret, lâf u güzâf, lecc ü inâd, cebe ve cevşen, ceng ü cidâl, dârât u 'ünvân, def' ü ref', devlet ü 'izzet, devlet ü ikbâl, etrâf u eknâf, evbâş u kallâş, feryâd u enîn, feryâd u figân, feryâd u vâveyla, lutf u ihsân, medh u sena, mekr ü al, men' ü def', meşakkat u zahmet, muzaffer u mansûr, nâlân ve giryân, nâle ü efgân, nâle ü zârî, neşv ü nema, nizâ' u cidâl, pend u nasihat, recâ u temenna, rey' ü tedbîr, sâg ve sâlim, şâd u handân, şerr u şûr, şükr u sipas, tek u tenhâ, tevbe ve istigfâr, yagmâ ve târâc, yât u yarak, zabt u tasarruf, zîb ü ziynet

\section{Manayı Kuvvetlendirmek İçin Kullandığı Zıt Anlamlı Kelimeler}

Gâh u bi-gâh, Hall u 'akd, Kibâr u slgâr, Re'âya ve berâya, Rûz u şeb, Yemîn ü yesâr, Zîr ü zeber

\section{Manayı Kuvvetlendirmek İçin Kullandığı Ayetler}

Afâllâhu 'ammâ selef', (v)elfitnetu eşeddu mine-lkatl', eleyse-ssubhu bikarib(in $)^{5}$, es sulhu hayr(un $)^{6}$, eynel meferr $(u)^{7}$, fe cealehum keasfin me'kûl ${ }^{8}$, fe hezemûhum bi iznillâhi ${ }^{9}$, fe izâ hiye temûr ${ }^{10}$, fefirrû ila(A)llâhî ${ }^{11}$, ferîkun fil cenneti ve ferîkun fîs saîr(saîri) ${ }^{12}$, fi kulûbihim meradun ${ }^{13}$, hâtû bûrhânekum ${ }^{14}$, ihbitû misran ${ }^{15}$, innâ lillâhi ve innâ ileyhi râciûn(râciûne) ${ }^{16}$, innallâhe azîzun zuntikâm(zuntikâmin) ${ }^{17}$, innel fadla bi yedillâhi ${ }^{18}$, irame zâti-l'imâd(i) Elletî lem yuhlak misluhâ fîllbilâd(i) ${ }^{19}$, irci' î ilâ rabbiki râdiyeten merdiyye(ten $)^{20}$, kullu men aleyhâ fân(fânin ${ }^{21}$, kullu şey'in hâlikun illâ

\footnotetext{
${ }^{3}$ Mâide: 5/95: Allah geçmiştekileri affetmiştir.

${ }^{4}$ Bakara: 2/191: Fitne ç1karmak adam öldürmekten daha kötüdür.

${ }^{5}$ Hûd:11/81: Sabah vakti yakın değil mi?

${ }^{6}$ Nisâ: 4/128: Sulh daha hayırlıdır.

${ }^{7}$ Kıyamet: 75/10: Kaçış nereye?

${ }^{8}$ Fil: 105/5: Böylece onları yenilmiş ekin yaprağı gibi yaptı

${ }^{9}$ Bakara: 2/251: Allah'1n izniyle onları bozguna uğrattılar.

${ }^{10}$ Mülk: 67/16: Yeryüzü sarsıldığı zaman

11 Zâriyât: 51/50: Öyleyse Allah'a sığının

${ }^{12}$ Şûrâ: 42/7: Onların bir kısmı cennete ve bır kısmı cehennemdedir.

${ }^{13}$ Bakara: 2/10: Onların kalplerinde hastalık vardır

${ }^{14}$ Enbiyâ: 21/24: Haydi delilinizi getirin

${ }^{15}$ Bakara: 2/61: Öyleyse inin şehire

${ }^{16}$ Bakara: 2/156: Allah'a aidiz ve ona döneceğiz derler

17 İbrahim: 14/47: Muhakkak ki Allah azizdir, intikam sahibidir.

18 Âl-i İmrân: 3/73: Lutuf Allah'in elindedir.

${ }^{19}$ Fecr: 89/7-8: Sutunlara sahip İrem şehrine, O ki beldeler içinde onun bir benzeri yaratılmadı.

${ }^{20}$ Fecr: 89/28: Sen O’ndan razı, O da senden razı olarak Rabbine dön!

${ }^{21}$ Rahmân: 55/26: Yer üzerinde bulunan her canlı yok olacaktır.
} 
vecheh(vechehu ${ }^{22}$, lâ yus-elu 'ammâ yef'alu ${ }^{23}$, lem yuhlak misluhâ fîllbilâd(i ${ }^{24}$, eleyse subhu bi karîb ${ }^{25}$, nasrun minallâhi ve fethun karîb(karîbun) ${ }^{26}$, selâmun kavlen min rabbin rahîm $^{27}$, tilke aşaratun kâmileh(kâmiletun) ${ }^{28}$, tû̀'til mulke men teşâu ve tenziul mulke mimmen teşấ'(teşâu ${ }^{29}$, faktulû-l müşrükîne ${ }^{30,}$ va(A)llahu 'alâ kullî şey-in kadî̀ ${ }^{31}$, ve-izâlvuhûşu huşirat ${ }^{32}$, ve enzelnâl hadîde fihi be 'sun şedîdun ${ }^{33}$, ve fethun karîb(karîbun) ${ }^{34}$, ve huşire li suleymâne cunûduhu ${ }^{35}$, ve inneke le alâ hulukin azîm(azîmin) ${ }^{36}$, ve lekad ketebnâ fiz zebûri minba'diz zikri ennel arda yerisuhâ ıbâdiyes sâlihûn ${ }^{37}$, ve mâ erselnâke illâ rahmeten lil âlemîn(âlemîne) ${ }^{38}$, ve mâ liz zâlimîne min ensâr (ensârin) ${ }^{39}$, ve şâvirhum fil emr(emri) ${ }^{40}$, ve yensuraka(A)llâhu nasran 'azîzâa(n) ${ }^{41}$, vecâhedî fî sebîli(A)llahi ${ }^{42}$, vekâne hakkan 'aleynâ nasru-lmuminîn(e $)^{43}$, vekul câe-lhakku vezehekalbâtill $(u)^{44}$, velehu-lcevâri-lmunşeâtu fî-lbahri kel-a lâm(i) ${ }^{45}$, vemâ-nnasru illâ min 'indillâh ${ }^{46}$, ves selâmu ala menittebeal hudâ ${ }^{47}$, vesâri' $\hat{u}$ ilâ magfiratin min rabbikum vecennetin 'arduhâ-ssemâvâtu vel-ardu uiddet lilmuttekîn(e) $)^{48}$, yâ dâvûdu innâ cealnâke halîfeten fil ardi ${ }^{49}$, yâ eyyuhâ-nnebiyyu câhîdî-lkuffâra velmunâfikîne ${ }^{50}$, yef'alu(A)llâhu mâ yeşâ $\hat{~}^{51}$, yefrahul mu'minûn (mu'minûne) bi Nasrillah ${ }^{52}$, yevme lâ yenfau mâlun ve lâ

\footnotetext{
${ }^{22}$ Kasas: 28/88: O'nun zatından başka her şey yok olacaktır.

${ }^{23}$ Enbiyâ: 21/23: O, yaptığından dolayı sorgulanamaz fakat onlar sorgulanırlar.

${ }^{24}$ Fecr: 89/8: O ki beldeler içinde onun bir benzeri yaratılmadı.

${ }^{25}$ Hûd: 11/81: Sabah yakın değil mi?

${ }^{26}$ Saff: 61/13: Allah'tan bir yardım ve yakın bir fetih

${ }^{27}$ Yâsin: 36/58: Çok merhametli olan Rab'den bir söz olarak (kendilerine) "Selâm” (vardır).

${ }^{28}$ Bakara: 2/196: tam on gün

${ }^{29}$ Âl-i İmrân: 3/26: Mülkün mâliki olan Allah'ım. Mülkü dilediğine verirsin ve dilediğinden mülkü alırsın

${ }^{30}$ Tevbe: 9/5: Allah'a ortak koşanları artık bulduğunuz yerde öldürün

${ }^{31}$ Âl-i İmrân: 3/29; Haşr: 59/6; Enfâl: 8/41: Allah, her şeye hakkıyla gücü yetendir.

${ }^{32}$ Tekvir: 81/5: Yaban hayatı yaşayan (irili ufakl1) tüm canlılar toplandığ 1 zaman

${ }^{33}$ Hadîd: 57/25: Kendisinde müthiş bir güç ve insanlar için birçok faydalar bulunan demiri yarattık

${ }^{34}$ Saff: 61/13: ve yakın bir fetih

${ }^{35}$ Neml: 27/17: Süleyman'ın, cinlerden, insanlardan ve kuşlardan meydana gelen orduları onun önünde toplandi.

${ }^{36}$ Kalem: 68/4: Sen elbette yüce bir ahlâk üzeresin.

${ }^{37}$ Enbiyâ: 21/105: Andolsun, Zikir'den (Tevrat'tan) sonra Zebûr'da da, "Yere muhakkak benim iyi kullarım varis olacaktır" diye yazmıştık.

${ }^{38}$ Enbiyâ: 21/107: (Ey Muhammed!) Seni ancak âlemlere rahmet olarak gönderdik.

${ }^{39}$ Mâide: 5/72: Ve zalimler için bir yardımcı yoktur.

40 Âl-i İmrân: 3/159: İs konusunda onlarla müşavere et

${ }^{41}$ Fetih: 48/3: Allah sana, şanlı bir zaferle yardım etsin

${ }^{42}$ Bakara: 2/218: Allah yolunda cihad edenler

${ }^{43}$ Rûm: 30/47: Mü'minlere yardım etmek ise üzerimizde bir haktır

${ }^{44}$ İsrâ: 17/81: Hak geldi, batıl yok oldu

${ }^{45}$ Rahmân: 55/24: Denizde akıp giden dağlar gibi yüksek gemiler de O’nundur.

46 Âl-i İmrân: 3/126: (vemâ-nnasru illâ min 'indillâhi-l'azîzi-lhakîm): Yardım ve zafer ancak mutlak güç sahibi, hüküm ve hikmet sahibi Allah katındadır.

${ }^{47}$ Tâhâ: 20/47: Selâm, doğru yola uyanlara olsun

${ }^{48}$ Âl-i İmrân: 3/133: Rabbinizin bağışına, genişliği göklerle yer arası kadar olan ve Allah'a karşı gelmekten sakınanlar için hazırlanmış bulunan cennete koşun.

${ }^{49}$ Sâd 38/26: Ey Dâvûd! Gerçekten biz seni yeryüzünde halife yaptık

${ }^{50}$ Tevbe 9/73: Ey peygamber! Kâfirlere ve münafiklara karșı cihad et ve onlara karşı çetin ol

${ }^{51}$ İbrahim 14/27: Ve Allah dilediğini yapar.
} 
benûn(benûne), İllâ men etâllâhe bi kalbin selîm(selîmin) ${ }^{53}$, yevme yefirrul mer'u min ehih $(i)^{54}$

\section{Manayı Kuvvetlendirmek İçin Kullandığı Hadis -i Şerifler}

el veledü sırrl ebîhi ${ }^{55}$, et teennî min er Rahman vel acîle fì 'l eşşeytân ${ }^{56}$, hayr el umur evsatuha ${ }^{57}$, hubb ül vatan min el imân ${ }^{58}$, hubb-ud-dünyâ re'sü külli hatietin ${ }^{59}$, şâhetil vîcûh ${ }^{60}$, tenâkehî tenâselûu ${ }^{61}$

\section{Manayı Kuvvetlendirmek İçin Kullandığı Deyimler}

Aç kurt koyun sürüsüne dalar gibi dalmak, Ata oğula oğul ataya bakmaz oldu, Çiftçi eline düşmüş doğana dönmek, Eli bağlı ciğeri dağll, Kuskuna kuvvet kamçıya bereket, Okları atılıp yayları basılmak, Ölmüss kanberi azat etmek, Var kuvvetin bazuya getirmek.

\section{Sonuç}

XVII. yüzyıl, Mehmed bin Mehmed, Mustafa Koçibey, İbrahim Peçevi, Kâtip Çelebi, Müneccimbaşı Ahmed bin Lütfullah ve Mustafa Naima gibi Osmanlı Tarihçiliği konusunda ün yapmış tarihçilerin eserlerini kaleme aldıkları, Osmanlı tarih yazıcıllğı açısından oldukça önemli bir dönemdir. XVII. yüzyılda Osmanlı tarih yazıcıllğının önemli örneklerinden bir diğeri ise Solak-zâde Mehmed Hemdemî Çelebi'nin kaleme aldığı ve Solak-zâde Tarihi olarak bilinen Nevâdirü'l Vukū' isimli eseridir. Çeşitli kaynaklardan derlenerek oluşturulan eser, Joseph Von Hammer tarafindan Osmanlı Tarihi hakkında yazılmış en faydalı hülasa olarak tanımlanmışıtır. Esere ait yurtiçindeki ve yurtdışndaki kütüphanelerde birden çok el yazması eser bulunmakla birlikte bu nüshalar içerisinde Avusturya Milli Kütüphanesinde bulunan A.F.15 (472) arşiv numaralı nüsha müellifin müsveddesi olması sebebiyle diğerlerinden daha değerli ve orjinaldir. $\mathrm{Bu}$ nüsha içerdiği konular, kullanılan kaynaklar bakımından diğerlerinden ayrılmaktadır. Esere ait nüshalar, Osmanlı Devleti'nin kuruluşundan başlasa da bitişi nüshalara göre farklılık göstermektedir. Farklılı̆̆ın oluşmasında en önemli etken müellifin eserini tamamlayamamasından kaynaklanmaktadır. Müellifin kendi çağdaşı olan tarih yazarlarının gölgesinde kalmasının belki de en önemli sebebinin önemli bir memuriyette bulunmamış olmasından kaynaklandığı söylenilebilir. Örneğin Tacü’t-Tevârîhîn yurtiçinde ve yurtdışında tespit edebildiğim kadarıyla 120'den fazla nüshasının olması ve

\footnotetext{
${ }^{52}$ Rûm 30/4-5: O gün Allah'ın (Rumlara) zafer vermesiyle mü'minler sevinecektir. Allah, dilediğine yardım eder. O, mutlak güç sahibidir, çok merhametlidir.

${ }^{53}$ Şuarâ 26/88: O gün ki ne mal fayda verir ne oğullar!

${ }^{54}$ Abese 80/34: O gün kişi kardeşinden kaçar.

${ }^{55}$ Hadis-i Şerif: Çocuk Babasının sırrıdır.

${ }^{56}$ Hadis-i Şerif " Dikkat ve temkinle hareket etmek Rahmandandır acele etmek ise şeytandandır"

${ }^{57}$ Hadis-i Şerif: "Herşeyin ortasını bulun."

${ }^{58}$ Hadis-i Şerif: Vatan sevgisi imândandır.

${ }^{59}$ Hadis-i Şerif: "Dünya sevgisi bütün günahların başıdır

${ }^{60}$ Hadis-i Şerif: "Yüzler yere sürünsün."

${ }^{61}$ Hadis-i Şerif: Evleniniz çoğalınız.
} 
bunun yanında Solak-zâde Tarihi'nin tespit edilebilen nüsha sayısının sadece 17 olması bu durumun kanıtı olarak görülebilir. Ayrıca eserin toplama bir eser olması ve orijinal olmaması da o dönemde ve öncesinde yazılan eserlere göre geri planda kalması sonucunu doğurmuş olabilir. Müellifin anlatımı zenginleştirmek için kullandığı deyimlerin ve atasözlerinin bugün bile kullanıldığı görülmektedir. Yine o dönemin tarih yazıcılı̆̆ında anlatımı güçlendirmek için yaygın olarak kullanılan ayetlere ve hadislere çokça yer verilmiştir. Bunun yanında Arapça ve Farsça beyitlerde eserde çokça kullanılmıştır. Eser orjinallikten uzak olsa da gerek dil ve anlatım bakımından çağdaşlarına göre çok daha sade olması ve gerekse olayları uygun bir şekilde özetlemesi sebebiyle Osmanlı Tarihi açısından önemli bir kaynak olma niteliği taşır. 


\section{Kaynaklar \\ Kaynak Eserler}

Altınay, Ahmed Refik, Âlimler ve Sanatkârlar, İstanbul 1924.

Bursalı Mehmed Tahir Bey, Osmanll Müellifleri, İstanbul 1342.

Edirneli Mehmed b. Mehmed, Nuhbetü't-Tevârih ve'l-Ahbâr, İstanbul 1276.

Evliya Çelebi, Seyahatname, İstanbul 1314.

Gelibolulu Mustafa Âlî, Künhül Ahbâr, Türk Tarih Kurumu, Ankara 2009.

Hoca Sadeddin Efendi, Tacü’t Tevârih, İstanbbul 1862.

Selânikî Mustafa Efendi, Selânikî Tarihi, İstanbul 1281.

Sülâle -i Selâtin -i Al -i Osman ve Ricâl -i Devlet, TBMM Arşivi, Arşiv No: Hk.187.

\section{Araştırma-İnceleme Eserleri}

Afyoncu, Erhan, Tanzimat Öncesi Osmanlı Tarihi Araşstrma Rehberi, İstanbul 2007.

Arıkan, Zeki, "Tarih", Türkiye Diyanet Vakfi İslam Ansiklopedisi, Cilt:40, s: 69

Babinger, Franz, Osmanl Tarih Yazarları ve Eserleri, (Çev.: Coşkun Üçok), Ankara 1982.

Baysun, M. Cavit, "Hasan Beyzâde Ahmed Paşa", Türkiyat Mecmuasl, C:10, 1953.

Buttanrı, Halil, "Fuâd Köprülü'nün "Osmanlılarda Nakış Tarihine Dair" İsimli Beş Makalesi", Osmangazi Üniversitesi Sosyal Bilimler Dergisi, Yı1: 2001

Büyük Larousse Sözlük ve Ansiklopedisi, "Solak-zâde Mehmed Hemdemî Çelebi", C: 17

Çabuk, Vahid, Solak-zâde Tarihi, Ankara 1989.

Gelibolulu Mustafa Ali, Nusret-nâme, Hazırlayan: Mustafa Eravcı, TTK Yayınları, Ankara 2014

Güftî, Teşrîfâtü' 'ş-Şuarâ, (Haz. Kâş̧if Yılmaz), Ankara 2001.

Hammer, Joseph Von, Büyük Osmanlı Tarihi, (Haz.: Mümin Çevik - Erol Kılıç), Üçdal Neşriyat, İstanbul 1999.

Hüseyin TUGİ, Musibetnâme, (Haz. Nezihi Aykut), Türk Tarih Kurumu Yayınları, Ankara 2010.

Kuruçay, Akif-Dereli, Sabri, İstanbul'un 100 İlim ve Fikir Adamı, Kültür A.Ş. Yayınları, İstanbul 2012.

Mehmed Süreyya, Sicill-i Osmanî, (haz. Nuri Akbayar), İstanbul 1996.

Mustafa Safâyî Efendi, Tezkire (haz. Pervin Çapan), Atatürk Kültür Merkezi Yayınları, Ankara 2005.

Özcan, Abdulkadir, "Solak-zâde Mehmed Hemdemî", Türkiye Diyanet Vakfi İslam Ansiklopedisi, Cilt: 37.

Özcan, Emine Sonnur, "Bir Sosyal Tarih Kılavuzu Olarak Târih-i Selânikî", OTAM, Say1:37, 263-288

Özergin, M. Kemal, "Solak-zâde" İA, C: X, s: 749.

Özkan, İsmail Hakk1, "Muhayyer", Türkiye Diyanet Vakfi İslam Ansiklopedisi, C: 31, s: 22-23.

Özkan, İsmail Hakk1, "Rast", Türkiye Diyanet Vakfi İslam Ansiklopedisi, C: 34, s: 462.

Togan, Zeki Velidi, Tarihte Usul, İstanbul Üniversitesi Edebiyat Fak., 1950.

Yeni Türk Ansiklopedisi, "Solak-zâde Mehmed Hemdemî Çelebî", Ötüken Neşriyat, İstanbul 1985, C: 9. 
